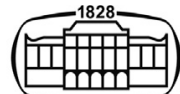

AKADÉMIAI KIADÓ

Journal of Adult

Learning, Knowledge and Innovation

4 (2021) 2, 76-87

DOI:

10.1556/2059.2021.00051

(c) 2021 The Author(s)

ORIGINAL RESEARCH

PAPER

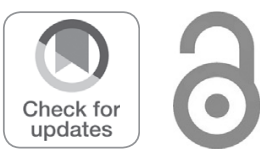

\section{Education sector policies and their role in the integration of workplace learning and higher education: A case of Tanzania's higher technical and engineering education}

\author{
JAMES ELIKANA MMARI ${ }^{1^{*}}$, ZSUZSA KOVÁCS ${ }^{2}$ (D) and \\ CSABA KÁLMÁN ${ }^{3}$ • \\ ${ }^{1}$ Doctoral School of Education, Faculty of Education and Psychology, Eötvös Loránd University, \\ Budapest, Hungary \\ ${ }^{2}$ Institute of Research on Adult Education and Knowledge Management, Eötvös Loránd University, \\ Budapest, Hungary \\ ${ }^{3}$ Department of English Applied Linguistics, Eötvös Loránd University, Budapest, Hungary
}

Received: July 9, 2021 • Accepted: October 17, 2021

Published online: January 21, 2022

\begin{abstract}
Tanzania's education system has been passing through different changes in its policies and strategic implementation plans. As a result, improvements in various areas, such as increased students' enrolment rate, improved pass rates, and improved infrastructure at all levels have been realized. This pilot study aimed at understanding the awareness and perception of policymakers, employers, instructors, and students of the importance of policies in integrating workplace learning and technical higher education. With the main question being, how stakeholders in the education sector perceive the importance of policies in integrating workplace learning and technical higher education. In order to answer the above question, a qualitative study with semi-structured interviews was conducted with policymakers, employers, instructors, and students. Most of the interviewees stated that policies have significant roles in ensuring the smooth integration and implementation of these two learning modes. On the other side, several challenges were mentioned in policy implementation and realization of the strategic plans. These challenges were categorized as those related to the public's and students' awareness and readiness, financial constraints, educational institutes' readiness, and operationalization of the organizations and educational institutes. From this pilot study, insightful information is gained on the importance of having policies that take into account all main stakeholders in higher education.
\end{abstract}

\section{KEYWORDS}

educational policies, workplace learning, technical education, higher education

\section{INTRODUCTION}

This article provides a thorough understanding of various educational stakeholders' perception on the importance and role of the educational policies in integration of workplace learning and higher technical education using technology. Understanding how broad this concept is, this article focuses on building the ground understanding of the stakeholders understanding on the roles and the challenges that educational policies are facing in enabling this integration through a qualitative inquiry, this foundation will be later used to build broader and deeper research on the themes surrounding the topics of educational policies, workplace learning, technical education and how technology is supporting the integration. 
Furthermore, understanding the importance of identity formation at the workplace, the author also included viewers' understanding on how policies could help them in formation of their professional identity when they are well applied and integrated in their institutes.

In its earlier section, the article discusses the Tanzanian education system and its structure to give a reader an abstract understanding of the education system in the selected population. Thereafter, it gives the review of various theoretical concepts in connection with the main idea of integrating workplace learning and technical higher education through technology.

The article then gives the results of the qualitative inquiries, discusses various themes that emerged from the inquiry, it gives a conclusion on the possible way forward and the efficacy of the tested data collection tool.

\section{An overview of education sector in Tanzanian context}

In the past two decades, Tanzania's education system has gone through various improvements which have led to not only positive impacts but also more challenges to the involved stakeholders in ensuring that the quality of education keeps improving despite the changes and challenges (United Republic of Tanzania, 2000; Ministry of Education and Vocational Training (MoEVT), 2008; United Republic of Tanzania, 2016b). One of the sectors of education that have been affected by these developments and changes is technical education and vocational training. Many universities and technical colleges have improved their program and increased the number of professional programs offered, which has also brought an increase in the number of students enrolled in each academic year (TCU, 2010; United Republic of Tanzania, 2013, 2017). Another area that has improved significantly and impacted the education sector is the use of Information and Communication Technology (ICT), as many universities, colleges and schools have in one way or another adopted and introduced technology to facilitate various teaching and learning activities, such as student management, subject delivery, quality assurance and performance evaluation (United Republic of Tanzania, 2016b, 2017).

The government of Tanzania has also invested extensively in various ways of using technology in the education sector, such as introducing a centralized network among the universities and colleges, centralized admission and enrollment systems, and many other software and hardware infrastructures have been put in place to support the operation of the education sector (Mahenge \& Sanga, 2016; Tanzania Commission for Universities, 2010; Ministry of Education and Vocational Training (MoEVT), 2008; United Republic of Tanzania, 2016b, 2017; Vieira do Nascimento \& ValdésConterá, 2018).

Furthermore, the industry sector has also been affected in various ways, first by receiving students from these colleges and universities who would like to pursue industrybased training for a certain period as part of their curriculum requirements. Second, there is an increased number of employees who attend technical universities and colleges to upgrade their academic qualification via either part time studies or evening programs. Taking into account, how technology has been used in facilitating teaching and learning, workplace learning and technical higher education, have now been brought closer not only by the students who attend industrial training in these companies, but also via employees who attend higher technical education. These students bring in new knowledge from the education sector and they also take in new practical and hands-on skills of performing various tasks to their particular engaged learning and teaching environment, which affects their academic institutions, educators as well as their fellow students and co-workers.

\section{Education system in general}

The education system lies under 2-7-4-2-3+ structure, whereby the Pre-primary school takes 2 years, then 7 years for primary school, followed by 4 years of ordinary level secondary education, 2 years of advanced secondary school and at least 3 years of higher education (NUFFIC, 2015). To be admitted in public ordinary and advanced level secondary schools, learners have to achieve the minimum required grades upon seating for national examinations set at each exit from primary education to advanced secondary education. Failure to that, learners can take similar education under private owned schools. Students who achieve minimum required grades for entering higher education have to apply for higher education institutions at the central admission system, thereafter, based on the set entry requirement in various universities, institutes and colleges, students will be admitted in both public and private higher education institutes. Graduates from ordinary level secondary schools have alternative options of joining higher education institutes or teacher education system to pursue 2- or 3 -years diploma programs offered by both private and public higher education. Furthermore, students who failed to acquire the required minimum pass for admission in ordinary level, advanced level or higher education, can opt to join vocational education programs offered and administered by the Vocational Education and Training Authority (VETA). Therefore, in general the Tanzanian education system structure has several paths and alternatives that enable and accommodate all kinds of learners to make sure that no one is left behind. More government policies and laws are being amended and formulated to make sure that more alternatives are put in place for students with various cases that were not seen before.

\section{Education sector achievements}

In the past two decades, many changes have been taking place in Tanzania's education system, several policies related to education and technology have been developed and others have been amended. Such education sector policies and programs include the Technical Education and Training Policy (1996); Higher Education Policy (1999); Information and Communication Technology Policy for Basic Education 
(2007), Primary Education Development Plan (PEDP, 20022011), Secondary Education Development Plan (SEDP, 2004-2009); Educational Sector Development Program (ESDP, 1997) and Adult and Non-Formal Education Strategy (2003/04-2007/08); the overall policy is the Education and Training Policy (1995, 1999 and 2014). All of these have contributed significantly to the reshaping and improved education service in the country (Ministry of Education and Vocational Training (MoEVT), 2008; United Republic of Tanzania, 2012, 2017).

The 2016/17-2020/21 Education Sector Development Program has pointed out several achievements by these implementation plans as observed from various reviews:

enrolment for pre-primary education has reached 44.6 percent in 2017, which is one the highest in the sub-Saharan African region. The primary education gross enrolment rate has almost become universal (96.9\%) with net enrolment at $84 \%$, and more than $70 \%$ of the primary school leavers transition to secondary education. Higher education has also expanded rapidly from fewer than 20 higher education institutions in 2005 to more than 50 in 2016, with the enrollment more than quadrupling over the past decade, from less than 40,000 in 2005 to more than 200,000 in 2015 (United Republic of Tanzania, 2017: 3).

Other achievements regarding technical and vocational training have been embodied by an increase in the number of individuals entering the workforce with tertiary education, which has steadily increased from 1\% in 2007 to 3\% in 2016. Enrolment in Technical and Vocational Education and Training - TVET Institutes increased by $34.8 \%$ from 145,511 in 2011 to 196,091 in 2015 , and graduates increased by $64 \%$ from 110,014 to 180,450 during the same period. Registered technical education institutions numbered 323 in 2014 (up from 170 in 2007), enrolling approximately 116,000 learners (United Republic of Tanzania, 2017). It is noticeable that policies and implementation plans help the Government and its institutions in achieving its vision and goals.

\section{Education sector challenges}

However, the implementation of the plans depends solely on the Government's priorities. For example, as far as sector priorities are concerned, there was an increase of 22 percent of funds allocated to the education sector in the financial year 2016/17 compared to that of 2015-16; however, there was a slight reduction of 1.3 percent in the financial year 2017-18. In general, there's an increased commitment of the government in providing universal basic education, although the focus was given to primary education with the new feefree education policy being given the highest priority (United Republic of Tanzania, 2017).

On the other hand, the revised editions of Tanzania's Education Sector Development Program (ESDP 2007/082016/17, 2016/17-2020/21), have pointed out several challenges facing the education sector. They include the lack of effective links and synergies within the education sector, inadequate funding of education programs and lack of an education system that addresses cross-cutting issues
(Ministry of Education and Vocational Training (MoEVT), 2008; United Republic of Tanzania, 2017). Although the program has set out several key components that support TVET, yet none of the components focus on the integration or strengthening collaboration between educational institutes and industries, let alone the use of technology in this collaboration. This, in turn, led to another critical challenge, a mismatch between the output of higher education institutions and labor market needs. This discrepancy is exacerbated by the inadequate and/or outdated curricula that lack direct relations to industries. Consequently, there is a lack of technology transfer and its application in economic activities, which requires urgent attention from policy developers, decision makers and low level policy implementers (United Republic of Tanzania, 2017).

A need for smooth transition and adaptation of new ways of delivering and acquiring skills and knowledge requires the implementation of reliable and effective policies to facilitate and accommodate these kinds of transition and challenges (Bell \& Stevenson, 2006). Therefore, it is important to see what role policies play, if any, what challenges they might face and how stakeholders in the education sector perceive the importance of these educational policies.

\section{REVIEW OF THE LITERATURE}

This section is a review of various articles in relation to the main concepts of this article are being discussed. The review has been structured based on the main concepts so that it can give the reader a good understanding of those concepts in relation to this article's main objectives.

\section{Educational policy}

In fact, policy is a broader term, however it can abstractly be defined as a set of principles created with the intent of guiding actions and achieving sensible outcomes. A policy is a statement of commitment that is carried out through a method or protocol. A governance body inside an institution usually adopts policies so that in one way they provide means of measuring the efficiency, effectiveness, economy, and accountability on their day-to-day performance towards the organizational goals.

When it comes to educational policy, these are the ones that have emerged in the educational spheres, and they have been influenced by both psychological theories of learning and improvements in psychometric tools that measure student learning. Many educational strategies developed in the twenty-first century are more responsive to students' academic progress and the elements that may influence teaching and learning process $(\mathrm{Ku}$, Phillipson, \& Phillipson, 2015). To effectively attain the intended goals, policies are supported by strategies and planning guideline, which provides road maps for the implementation of the policy and also defines the targets, activities and timeline for implementation of the policy and strategy, it also defines responsibilities and resources needed for the successful 
realization of the two predecessor documents (Yano, 2013). These three components of any policy formulation play a vital role in shaping and directing the successful implementation of education systems in any country or state. With strong and committed leadership from top-down management, with the inclusion of all involved stakeholders in daily education activities, such as school, college and university leaders, principals, managers, teachers as well as students, policies are the best tools towards successful impacts on education in any society (Bell \& Stevenson, 2006).

\section{Technical and vocational education and training}

Being one of the major factors in driving a country's economy (Pavlova, 2014), technical and vocational education in this context covers all engineering, technical and vocational related education offered within the education framework of a particular country. In this article, the focus of which is Tanzania's education system, it provides engineering and technical education under various schemes. Low level is administered by the Vocational Education and Training Authority (VETA), while intermediate to higher level is administered and accredited by both the National Council for Technical Education (NACTE) and the Tanzania Commission for Universities (TCU). The low-level Technical and Vocational Education Training (TVET) allows youth and even adult learner graduates from primary education and middle secondary education to be admitted for certificates and diploma levels studies. On the other hand, intermediate and higherlevel, which is mainly referred to as engineering and technical education, provides room for graduates from middle level secondary education to undergraduates to enroll into Technical Education and Training colleges (TET), institutes and universities. Upon successful completion, TET graduates are awarded a diploma, Bachelor's, Master's and Doctoral degrees (Ministry of Education and Vocational Training (MoEVT), 2008; United Republic of Tanzania, 2013).

\section{Workplace learning}

Workplace learning generally can be defined as the process of acquiring skills and knowledge formally or informally in the workplace settings. It excludes the formal learning process and formal professional training that leads to an individual's upgrade in certified qualification (Cacciattolo, 2015). Silverman (2003) categorized this learning process into three types, the in-house training, experienced-based learning, and continuous learning. Informal categories of workplace learning are silent and have a great impact on individuals at workplaces in their professional development as well as enhancing organizational performance; however, many formal education systems have not yet recognized and accommodated this kind of learning in their qualification frameworks (Silverman, 2003; Zhao \& Ko, 2018).

\section{Educational technology}

While acquiring knowledge and skills at any level of engineering, technical and vocational education in various settings, whether at the workplace or in an educational institute, various technological tools have been deployed and used to facilitate the teaching and learning process. Technological tools involved cover various aspects of the teaching and learning process, such as those of the management of education systems and processes (i.e., enrolment, admission, student management, etc.), pedagogical aspects of teaching and learning (i.e., content delivery and assessment of the teaching and learning processes, etc.), all aiming at facilitating successful acquisition of knowledge and skills (Ahmadigol, 2016; Bell, 2011; Kidd, 2010). Deployment and uses of these technological tools have brought major impacts and played vital roles in the success of the current education system. These technological tools support both the formal and informal teaching and learning process, whether in an educational institute or at the workplace settings (Johnson, 2011; Li, Wong, Cheung, Lam, \& Ng, 2015; United Republic of Tanzania, 2016b).

Considering the focus of this study, the aspect of education that has been affected by these changes, is the increased enrollment of employed students attending evening or full time studies. This is also caused by the fact that universities, institutes and colleges that used to focus on offering only a diploma (a three years' undergraduate program or technical certificates) have now expanded their scope into offering higher technical awards, such as Bachelor's, Master's and Doctoral degrees related to technical education as well as offering more demanding and technological programs in the country (Ministry of Labor, Employment and Youth Development 2007; NUFFIC, 2015; Tanzania Commission for Universities 2010; TCU, 2010; Ministry of Education and Vocational Training (MoEVT), 2008; United Republic of Tanzania, 2012, 2013, 2016a, 2017; Vieira do Nascimento \& Valdés-Conterá 2018).

With all these challenges and achievements invoked by several policy development and amendments, none of the policies have effectively and extensively addressed the integration of workplace learning and technical higher education yet, as well as the application and utilization of available technology and infrastructures laid down by the government. As was pointed out by the Education Sector Development Plan 2017/18-2020/21,

the usage of information and communications technologies (ICT) is inadequate. Despite the investment in ICT through the Science, Technology and Higher Education Project (STHEP) from 2008-2014, the capacity of the regulating Tanzania Commission for Universities (TCU) is low (p. 47).

According to Leydesdorff (2012), in line with the Triple Helix (TH) Model between industry, government and universities for the development of knowledge-based economies and Slotte and Tynjälä (2003) in accordance with the Industry-University collaboration for acquiring, developing, and retaining a skilled workforce, it is clear that the integration between workplace learning and technical higher education is one of the crucial aspects to be considered for successful professional development, which will, in turn, bring impacts to education systems as well to the industry 
and socio economics of a country. However, this kind of integration is not easily realized without an in-depth discussion from all concerned bodies as well as proper policies to support such integration (Slotte \& Tynjälä, 2003).

Understanding the importance of policies in effective integration of workplace learning and technical higher education in Tanzania and how the main involved stakeholders perceive the roles of these policies are the focus of this article.

\section{STATEMENT OF THE PROBLEM}

Technological tools play an important role in supporting teaching and learning processes, while educational policies equally play a vital role in supporting and laying down road maps for a smooth integration and deployment of workplace learning and technical education using available technological tools. However, from the reviewed literature, two main issues have emerged that require further research and have consequently been chosen for the focus of this article.

1. Availability of policies that support uses of technology in integrating workplace learning and formal technical higher education.

2. Stakeholders' understanding and perception of the roles performed by Tanzania's educational policies in integrating technical higher education and workplace learning.

The literature has shown that a lack of mainstream guidelines and policies that lead to formal recognition and integration of workplace learning and technical higher education, especially in developing countries, such as Tanzania, has been a reason for underutilization of technology in workplace learning and in the technical higher education sector as well as their integration. Also, this has led to a lack of recognition and certification of the skills acquired by employees via their workplace learning activities whether admitted or not admitted in technical higher education (Lusigi, 2019; Mathes, 2018; United Republic of Tanzania, 2016b).

Furthermore, little is known on how the stakeholders perceive and understand the importance of these policies and how they are involved from the stages of developing the policies, strategies and their implementation plans to their realization. Therefore, this article will yield results and discussion concerning the role of educational policies in the integration as well as stakeholders' perceptions, awareness and involvement in policy development and realizations.

\section{Aim of the study}

This study has been conducted for two purposes, the first is to pilot the data collection tool, the semi-structured interview guide with a view of testing its validity and reliability for later use in the full study settings. Second, for this particular article, focus was given to understanding the roles and constraints of the education sector policies as well as the perception of students, educators, employers and policy makers towards the development of policies that support integration of workplace learning and technical higher education using technology. This study is a part of a largerscale pilot investigation, of which the other three purposes were achieved and discussed in another article.

\section{Objectives of the study}

The large-scale study was conducted to achieve the following objectives:

1. To explore the roles of education sector policies towards the integration of technical or engineering education and workplace learning in universities/institutes/colleges through technology.

2. To explore the constraints facing education sector policies in integrating technical or engineering education and workplace learning in universities/institutes/colleges through technology.

3. To understand the awareness and perception of policymakers, employers, instructors, and students of the importance of policies in integrating workplace learning and technical higher education using technology.

\section{Research questions}

Based on the objectives of the study, four research questions were formulated, however, in this study, the focus is on the fourth question with its three sub questions.

RQ 4 What are the challenges faced by students, educators, employers and policy makers and their perception of the integration of workplace learning and higher technical education through technology?

a. What are the roles of policies in integration of workplace learning and higher technical education?

b. What are the constraints facing education sector policies in the use of technology in technical higher education?

c. What are the perceptions of students, educators, employers and policy makers of the integration of workplace learning and higher technical education through technology?

\section{RESEARCH METHOD}

This pilot study aimed to explore and understand the perceptions and experiences of students, educators, employers and policy makers concerning the roles of educational policies in the integration of technical or engineering education and workplace learning in universities/institutes/colleges through technology in Tanzania.

Apart from this, another purpose of the study was to test a semi-structured interview data collection tool devised for this study and expected to be used in the main study; therefore, a qualitative case study research design was selected. In this way, the researcher could describe the participants' perceptions, experiences and challenges in addition to testing and improving the data collecting instrument 
so that it can later be used in a wider population. In this particular article, focus is given to research question number four, with its three sub questions, since the first three questions are discussed in another article.

\section{Participants}

All first degree (Bachelor's Degree) students attending the evening program at Arusha Technical College (ATC), their employers, ATC academic staff and persons in charge of the education policy development under the Ministry of Education were the participants of this study. Arusha Technical College was purposefully selected for this pilot study due to easy accessibility of the participants by the researcher. Purposive sampling technique was applied to draw samples from the population. Table 1 below gives a detailed description of the participants.

\section{Research instrument}

The semi-structured interview guide was developed by the researcher based on the literature review and the objectives of the larger-scale study. It contained 21 open ended questions in the seven areas listed below. Since the sample contained three different categories of participants, the researcher tailored the questions to the specific category of the participant as necessary. Relationships between the questions in the research instrument and the research questions are shown in Table 2 below. However, this study focuses on the fourth research question of the larger-scale study. This fourth question has been broken down to three sub questions for easier and detailed understanding of the study.

a) demographics of the interviewees, i.e., names, occupation, level of study, programs they study/teach, organization or affiliation, job responsibilities, etc. b) overall understanding of the use of technologies in the teaching and learning process as well as their advantages and disadvantages

c) challenges faced in the use of technology for teaching and learning

d) overall understanding of workplace learning

e) overall understanding of educational policies

f) perceptions of the interviewees in the integration of workplace learning and technical higher education.

g) challenges of integrating workplace learning and technical higher education.

\section{Procedures}

The interviews took place between $31^{\text {st }}$ July, 2020 and $24^{\text {th }}$ November, 2020. Data collection was done through Skype and WhatsApp calls due to the geographical location of the researcher and the participants, and the interviews were conducted in the Swahili language, the mother tongue of the researcher and the participants. The interviews were recorded and later transcribed. Where necessary, interpretation from Swahili to English was done. The recording and interpretation were done after requesting the participants' permission. The recorded interviews yielded a very rich data base of 81,690 words.

\section{Data analysis}

Applying the bottom-up content analysis method, the transcribed interviews were analyzed in order to identify themes (Hsieh \& Shannon, 2005). Atlas.ti, qualitative content analysis software was used to help discover and organize themes and their categories to answer the research questions based on perceptions, challenges and experiences of the students, employers and educators.

Table 1. List of participants and their background information

\begin{tabular}{|c|c|c|c|}
\hline $\begin{array}{l}\text { Category of } \\
\text { participant }\end{array}$ & $\begin{array}{l}\text { Total number of participants in this } \\
\text { category }\end{array}$ & Affiliation/Institute/Organization & $\begin{array}{l}\text { Latest education level/Current level } \\
\text { of study }\end{array}$ \\
\hline Students & 4 & Arusha Technical College & $\begin{array}{l}2 \text { - BSc Information technology } \\
1 \text { - BSc Computer Science } \\
1 \text { - MSc Information System }\end{array}$ \\
\hline Educators & 4 & Arusha Technical College & $\begin{array}{l}1 \text { - MSc Sustainable Energy } \\
2 \text { - MBA Information Technology } \\
\text { Management } \\
1 \text { - BEng. Computer Engineering }\end{array}$ \\
\hline $\begin{array}{l}\text { Employers/ } \\
\text { Management }\end{array}$ & 4 & $\begin{array}{l}\text { 2- Arusha Technical College } \\
\text { 1- Crater IT } \\
\text { 1- Tanzania Broadcasting } \\
\text { Corporation }\end{array}$ & $\begin{array}{l}1 \text { - MA - Human Resource } \\
\text { Management } \\
1 \text { - BA - Human Resource } \\
\text { Management } \\
1 \text { - BSc Computer Science } \\
1 \text { - BA Human Resource } \\
\text { Management }\end{array}$ \\
\hline Policy makers & 3 & Ministry of Education & $\begin{array}{l}2 \text { - MA - Education Management } \\
1 \text { - MA - Technical Education } \\
\text { Management }\end{array}$ \\
\hline In total & 15 & & \\
\hline
\end{tabular}




\section{FINDINGS}

In this section, detailed answers to the research questions are given after analyzing the transcripts of the interviews. The answers are structured systematically in Table 2 based on their categories and themes, thereafter detailed explanations with examples are given citing from the interviews where necessary. Acronyms of the participants' names are used to maintain anonymity of the participants.

As shown in Table 2 above, categories were driven from the interview questions related to the participants' perception and understanding of policies as well as the challenges related to the implementation of policies to support the integration of workplace learning and technical higher education. The main categories were:

1. Rationale of the policies in integration of workplace learning and technical higher education

2. Understanding and perception of educational policies by students, teachers, employers and policy makers.

3. Challenges related to implementation of educational policies that support integration of workplace learning and technical higher education.
In the following section, detailed explanations of the emerging themes related to the categories above with examples from the interviews are presented.

1. Rationale of the policies in integration of workplace learning and technical higher education

a. Driver in education needs and plans - All (15) interviewees perceived the implementation of educational policies as a key driver in meeting the key needs in education and fulfilling of educational plans from individuals, community, organizations/institutional to the government and to the country level. In their views, without attainable and reliable policies, it is impossible for a country to achieve its goals and meet the needs of its people. Effective policies provide a way and push the government to meet its citizens' needs and fight against the social economic challenges. One of the policy makers expressed this as follows:

Any government has its goals and vision, however for it to be able to achieve them, it has to develop policies and strategic plans which are then used as a guideline to what has to be done by concerned governing body, institutions and individuals so that the government has a smooth run in fulfilling its roles towards achieving its vision (DM).

Table 2. Distribution of research questions, categories and emerging themes in relation to interviewees' responses

\begin{tabular}{|c|c|c|c|c|c|c|c|c|c|c|c|c|}
\hline \multirow{2}{*}{$\begin{array}{l}\text { Research } \\
\text { Questions }\end{array}$} & \multirow[b]{2}{*}{ Categories } & \multicolumn{4}{|c|}{$\begin{array}{l}\text { No. of } \\
\text { Interviewees } \\
\text { related to this } \\
\text { category by } \\
\text { their type }\end{array}$} & \multirow{2}{*}{$\begin{array}{l}\text { Total no. of } \\
\text { Interviewees } \\
\text { related to this } \\
\text { category }\end{array}$} & \multirow[b]{2}{*}{ Emerging themes } & \multicolumn{4}{|c|}{$\begin{array}{l}\text { No. of } \\
\text { Interviewees } \\
\text { related to this } \\
\text { theme by their } \\
\text { type }\end{array}$} & \multirow{2}{*}{$\begin{array}{c}\text { Total no. of } \\
\text { Interviewees } \\
\text { related to this theme }\end{array}$} \\
\hline & & $S$ & $\mathrm{~T}$ & $\mathrm{E}$ & $\mathrm{PM}$ & & & $S$ & $\mathrm{~T}$ & $\mathrm{E}$ & $\mathrm{PM}$ & \\
\hline \multirow[t]{4}{*}{ RQ4.a } & $\begin{array}{l}\text { Rationale of the } \\
\text { policies in }\end{array}$ & 4 & 4 & 4 & 3 & 15 & $\begin{array}{c}\text { Driver in education } \\
\text { needs and plans }\end{array}$ & 4 & 4 & 4 & 3 & 15 \\
\hline & $\begin{array}{l}\text { integration of } \\
\text { workplace learning } \\
\text { and technical } \\
\text { higher education }\end{array}$ & & & & & & $\begin{array}{c}\text { Align with other } \\
\text { local and } \\
\text { international } \\
\text { policies }\end{array}$ & 2 & 3 & 2 & 3 & 10 \\
\hline & & & & & & & $\begin{array}{c}\text { Inclusion and } \\
\text { equality in } \\
\text { education }\end{array}$ & 2 & 4 & 3 & 3 & 12 \\
\hline & & & & & & & $\begin{array}{c}\text { Promote lifelong } \\
\text { learning }\end{array}$ & 1 & 3 & 2 & 3 & 9 \\
\hline \multirow[t]{3}{*}{ RQ4.b } & $\begin{array}{l}\text { Understanding and } \\
\text { perception of }\end{array}$ & 4 & 4 & 4 & 3 & 15 & $\begin{array}{c}\text { In depth } \\
\text { understanding }\end{array}$ & 1 & 3 & 3 & 3 & 9 \\
\hline & educational policies & & & & & & Abstract awareness & 4 & 4 & 4 & 3 & 15 \\
\hline & $\begin{array}{l}\text { by students, } \\
\text { teachers, employers } \\
\text { and policy makers }\end{array}$ & & & & & & $\begin{array}{l}\text { Overlapping of } \\
\text { policies }\end{array}$ & 1 & 4 & 3 & 3 & 11 \\
\hline \multirow[t]{4}{*}{ RQ4.c } & $\begin{array}{l}\text { Challenges related } \\
\text { to implementation }\end{array}$ & 2 & 4 & 4 & 3 & 12 & $\begin{array}{c}\text { Government } \\
\text { priorities }\end{array}$ & 4 & 4 & 4 & 3 & 15 \\
\hline & of educational & & & & & & Financial resources & 2 & 4 & 4 & 3 & 13 \\
\hline & $\begin{array}{l}\text { policies that } \\
\text { support the } \\
\text { integration of }\end{array}$ & & & & & & $\begin{array}{l}\text { Community } \\
\text { awareness and } \\
\text { involvement }\end{array}$ & 3 & 4 & 4 & 3 & 14 \\
\hline & $\begin{array}{l}\text { workplace learning } \\
\text { and technical } \\
\text { higher education. }\end{array}$ & & & & & & $\begin{array}{l}\text { Pressure from } \\
\text { global policies }\end{array}$ & 1 & 4 & 4 & 3 & 12 \\
\hline
\end{tabular}


b. Alignment with other local and international policies - More than a half (10) of the interviewees have shown their concern about the importance of the educational policies to be aligned with other local and international policies. They did consider it as one of the most important aspects that policy makers have to consider during any policy development. One of the participants emphasized this by saying the following:

There is no way you can skip international and other intergovernmental organizations' policies, because we are not alone in this world and we cannot live by our own rules and guidelines without considering our neighboring countries, we need to be aligned with other countries too (WM).

Inclusion and equality in education - Another very important aspect of policy that seemed to be raised by more than three quarters (12) of the participants is the fact that policies help in providing guidelines that consider equality in education. They pointed out that, through proper policy, equal distribution of both human and material resources can be taken care of through all levels of the education system as well as all areas within the country. Student participants agreed that a lot of consideration has been given to students with disabilities in many colleges and schools, and this was due to different policies that have been implemented to support students with disability and those which promote gender equality. One of the participants expressed this as follows: "Because of these policies, we have a greater number of girls attending primary schools than boys in some regions where before it was not possible to let girls go to school" (EM).

c. Promoting lifelong learning - Participants, especially teachers and policy makers perceive policies as one of the key tools in supporting lifelong learning. Guidelines and directives given by policies to the responsible governing bodies to consider lifelong learning aspects are more effective than those without guidelines. The policies help the government to cover and distribute required support to those institutes and governing bodies dealing with adult learning, vocational training and other minority types of education provided within the country.

2. Understanding and perception of educational policies by students, teachers, employers and policy makers

a. In depth understanding - All the interviewees have shown to have an abstract understanding of the educational policies, however, only one (1) student was able to provide in-depth understanding concerning educational policies within the country and more than half of the teachers and employers have shown to have in-depth understanding of the educational policies. b. Overlapping of policies - All policy makers, teachers and employers were concerned with the overlapping of the policies. They were able to identify that some of the policies are overlapping, contradicting each other or do not provide enough detailed information to help implementers follow them through for successful realization. In their explanation, they have pointed out the issue of having policies, which comes after users in the bottom levels have already started working, using or adopting new changes, technology or books. This was noted out by one teacher and one student that

There are a lot of conflicts when it comes to policies in this country. Some policies, especially those dealing with technology, come into operation later, while we in the education sector are already involved in the usage and adopting some technologies. It costs a lot when you are given new policies which have some guidelines not to use some kind of technology or not to implement a certain project while you are already in the middle of it or you have been using such a technology for a long time. Parents, teachers and even students are also confused with curriculum issues, especially in our primary and secondary education system, many things are changed after a few years of implementation, for example books, subjects and even curriculums are being changed year after year, parents, teachers are left confused which books we should use for teaching our kids (PK).

"Yes, we have challenges in following intergovernmental policies, because sometimes you find that our country is not ready to adopt such a policy due to our environment and culture" (DM).

3. Challenges related to the implementation of educational policies that support the integration of workplace learning and technical higher education.

a. Government priorities - Constant changes in government priorities have been seen as one of the major challenges facing policy implementation and realization. Leadership in government changes every five years, and sometimes within one particular government term ministers and principal secretaries to various ministries are being changed. When this happens, it affects the realization of some policies. This may be due to the fact that different leaders and decision makers come with different priorities, which in turn affects the motivation of low level policy implementers. This also happens due to miscoordinations of the policies, governing bodies and alignment among the central government, the local governments and other government bodies. An example from one of the policy makers saying that

You understand that we as a country do not have a main single policy document that sets the entire vision of the country, like where we want to be in twenty, or even fifty years to come. Our country is governed by the political party 
that won the election, and these political parties have their own agenda that they bring after every five years, these agenda differ from each other, even those which come from the same political party have different priorities after every five years. So, it is not easy to realize policies that were meant to be done a very long time ago, say more than ten years, leadership and even those supposed to implement them might change on the way, which most of the time leads to pausing or totally changing the policy implementation plans (WM).

b. Financial resources - After changes in priority, another challenge that was pointed out by most of the participants was the availability of sufficient financial resources to support the implementation of that particular policy strategic plan. Some policy guidelines are very good and promise better education achievements; however, their implementation requires a large amount of money which cannot be allocated by the government at once or in a given timeframe. This was noted by one student who pointed out that

You know the issue is not implementation of the policies, but the money to make those things happen. You need all schools or hospitals to be networked, have an electronic way of supporting teaching and learning or sharing new treatment methods, but where is the money to implement that centralized network? Yes, some schools and colleges, especially those in private organizations are able to implement them, but government owned schools and universities rely on the government's provision of financial resources, which is very bureaucratic (AM).

c. Community awareness and involvement - Almost all participants (14) have pointed out issues concerning community awareness. It is one of the other challenges facing the implementation of several policies in the country. If the community is not well involved or informed concerning new policies or changes in the current policy, it is not easy to accept changes or realize the benefits of such a policy easily. Most of the time decision making bodies forget the importance of involving or informing the community of the changes in policies from the very early stages of developing the policy, they bring in the policy when it is ready to be used without hearing the comments and suggestions from that particular community. This in turn, makes it difficult for the community to accept the policy or changes made by that particular policy, and educational policies are no exception. This was noted as low level users of the policy like students or citizens, and sometimes even teachers in schools are not aware of the changes made in policies or do not even know the existence of some guidelines concerning certain matters in education. A good example in this study is that students' in-depth understanding of policies concerning the integration of workplace learning and technical higher education was very low, only one (1) student demonstrated it.

d. Pressure from global policies - Another challenge which was articulated by all policy makers, teachers and employers was the pressure received by policies from other nations or intergovernmental organizations/unions. Most of the time, due to affiliations with other nations, member countries are forced to adopt some policies even if they were not ready for such policies. Tanzania has also faced such challenges and due to that, policies are either not implemented or partially implemented. One of the policy makers pointed out the following,

It is not easy to adopt and implement everything that comes from those big nations or organizations, our country is still young and underdeveloped, so some kinds of technological based education are not easily implementable in our country (EM).

\section{DISCUSSIONS}

The results have shown that having a reliable policy in place to support the integration is a very important aspect towards a successful integration of workplace learning and technical higher education using technology. On the other hand, the formulation and implementation of a policy in line with such an integration approach is faced with several challenges which might prevent the realization of the policy if it is not worked out properly.

The study has shown that policies play an important role as the key drivers for any effective changes in education or any other important matters within a particular country. This finding is in line with previous studies which pointed out that policy is goal-oriented and it is complex - it is the coordination of several courses of action, and not one discrete activity (Bell \& Stevenson, 2006). This is similar to what has been claimed by Bell and Stevenson (2006), in as much as a country's policies have a vital impact on defining what has to be done in daily activities by low levels of management and institutes, such as colleges and schools and also what needs to be done by individuals to realize the set goals and visions of the whole state.

Another aspect of the policy which has shown a great impact is the role of the policies in bringing inclusion and equality in the education sector. The findings show that with an appropriate policy to support the integration, the realization of an education system that will consider inclusive and equality matters in education will be taken into consideration. The current mode of education emphasizes that any form of education or method of delivering knowledge that occurs in any setting, must consider the importance of accommodating all types of learners and educators as they are the implementers of the actual learning and teaching process. These findings are also mentioned in other 
studies (Braunsteiner \& Mariano-Lapidus, 2014; Lusigi, 2019; Pather \& Slee, 2018; Walters, Yang, \& Roslander, 2012). These studies have pointed out the importance of having an educational policy that supports gender equality and inclusive education at all levels. This is also in line with the United Nations' Sustainable Development Goal 4, which lays emphasis on inclusive and equitable quality education (United Nations, 2015; UNESCO, 2015).

Another important aspect of the policy that was released by many stakeholders, especially the employees and the employer categories is in how the policies could help them develop a lifelong learning culture which will build and contribute in their professional development and hence enhance their understanding and practical application of their own professional identity. This is what various practitioners in workplace learning research have been claiming as one of the importance of having effective workplace learning practices (Billett, 2001; Margarayn, Littlejohn, \& Milligan, 2011; Margaryan, Littlejohn, \& Milligan, 2013; Zhao \& Ko, 2018).

Challenges related to government priorities, financial resources allocation, community awareness and stakeholder involvements are among the major challenges that are faced in Tanzania, this was also pointed out by the government recently released education sector development plan document. Similar findings were reflected in Ethiopia from the study by Pather and Slee (2018), showing that due to the lack of proper priority and structured careers, implementation of policies related to education, such as those of inclusive education are hardly realized at the community level, though the country is well known for promoting inclusive education at the global level.

Community involvement and awareness is another major challenge. Many countries in Africa have not considered low level stakeholders who are actually the main implementers of the policies as important aspects to be involved in policy development. Lusigi (2019) has pointed out the low priority given by governments to universities and colleges in African countries for the realization and implementation of national policies and development plans. In addition to that, the study pointed out that governments have not considered the development of a knowledge economy or putting more funds in higher education as vital components for national development.

Pather and Slee (2018) provides a good example of policy implementation in Zanzibar - which is an island part of Tanzania, the Zanzibar Educational Policy released in 2006, many similar challenges were observed in this study, such as a low distribution of the policy documents to low level policy implementers, teachers, parents and school administrators; furthermore, the issues of inclusive education are not well understood by teachers, students, school administrators and even officers in the ministry. Even though the policy elaborates on and adopts the abstract level definition of inclusive education, the internalization and operational definition of the term into practicability has not been executed; therefore, it is not really helping those minority groups.

These findings above provide insightful information concerning policy implementation in Tanzania and they set the ground for future policy makers and implementers to be cognizant of the reason that contributes to the failure of various policies. On the other hand, and most importantly for this particular study, this discussion section sets ground to the next phase of this study, which is data collection and analysis in a wider scope and participation of stakeholders.

\section{CONCLUSION}

The purposes of this study were; first, to test and validate a data collection tool, which is a semi-structured interview guide containing 21 open ended questions in seven areas. The second purpose was to understand the perception of students, educators, employers and policy makers toward the development of policies that support integration of the workplace learning and the technical higher education using technology with the help of the fourth research question. In response to the first purpose, it can be concluded that the semi-structured interview guide generated a rich source of data that was relevant to the original purpose of the study; therefore, it proved to be a valid and usable measurement tool. As regards the second purpose, the rich data made answering the research questions possible.

First of all, it can be concluded that a policy plays a vital role in the successful implementation of any educational system. Therefore, this new learning and teaching model should consider the development of an effective policy which will bring together all the concerned stakeholders and bodies so as to implement a successful realization of the model. The second aspect that emerged from the study is the importance of involving all stakeholders in realizing such a learning and teaching approach, as all stakeholders play an active role in assuring that the proposed knowledge and skills acquisition approach is reliable and effective. The third and last important aspect is that concerning the challenges in realizing the policies as well as the proposed model, although policies are vital components, yet are subject to several challenges to be successfully implemented.

This pilot study was limited to the purposely selected population of Arusha Technical College in Tanzania, however due to the pandemic situation caused by COVID-19, the interviews were conducted via mobile/internet communication. Another limitation of this study is the fact that the focus was given to the higher technical education and not lower-level vocational training colleges of which although there are many in Tanzania, they are not categorized as higher education.

A larger-scale study with the input from this pilot study is expected to be conducted in the near future, with the application of the tool created and validated in this study. It is also expected that the next phase will be conducted in the field, in Tanzania, with the participation of more than one technical higher education institutes and a larger sample size; therefore, the expected results can be hypothesized to be more generalizable within the Tanzanian context. 
Funding: This research was supported by the Stipendium Hungaricum Scholarship Programme by the Hungarian Government.

\section{REFERENCES}

Ahmadigol, J. (2016). New definition of educational teachnology. In M. Simonson (Ed.), 39th annual proceedings. The annual convention of the association for educational communications and technology, Las Vegas, NV (1-3). AECT.

Bell, F. (2011). Connectivism: Its place in theory-informed research and innovation in technology-enabled learning. The International Review of Research in Open and Distributed Learning, 12(3), 98. https://doi.org/10.19173/irrodl.v12i3.902.

Bell, L, \& Stevenson, H. (2006). Education policy: Process, themes and impact (1st ed.). Routledge.

Billett, S. (2001). Learning in the workplace: Strategies for effective practice (1st ed.). Routledge.

Braunsteiner, M.-L., \& Mariano-Lapidus, S. (2014). A perspective of inclusion: Challenges for the future. Global Education Review, 1(1), 32-43. Retrieved from https://eric.ed.gov/?id=EJ1055217.

Cacciattolo, K. (2015). Defining workplace learning. European Scientific Journal, ESJ, 11(10). Retrieved from https://eujournal. org/index.php/esj/article/view/5559.

Hsieh, H.-F., \& Shannon, S. E. (2005). Three approaches to qualitative content analysis. Qualitative Health Research, 15(9), 1277-1288. https://doi.org/10.1177/1049732305276687.

Johnson, M. (2011). Adult learners and technology: How to deliver effective instruction and overcome barriers to learning. USA: San Jose State University.

Kidd, T. T. (2010). Online education and adult learning: New frontier for teaching practices. New York: Information Science Reference, Hershey.

Ku, K. Y. L., Phillipson, S., \& Phillipson, S. N. (2015). Educational learning theory. In J. D. Wright (Ed.), International Encyclopedia of the social \& behavioral sciences (2nd ed., pp. 238-245). Oxford: Elsevier.

Leydesdorff, L. (2012). The triple helix, quadruple helix, ..., and an $\mathrm{N}$-tuple of helices: Explanatory models for analyzing the knowledge-based economy? Journal of the Knowledge Economy, 3(1), 25-35. https://doi.org/10.1007/s13132-011-0049-4.

Li, K. C., Wong, T.-L., Cheung, S. K. S., Lam, J., \& Ng, K. K. (Eds.) (2015). Technology in education: transforming educational Practices with technology. Springer Berlin Heidelberg.

Lusigi, A. (2019). Higher education, technology, and equity in Africa. New Review of Information Networking, 24(1), 1-16. https://doi.org/10.1080/13614576.2019.1608576.

Mahenge, M. P. J., \& Sanga, C. (2016). ICT for E-learning in three higher education institutions in Tanzania. Knowledge Management \& E-Learning, 8(1), 200-212. https://doi.org/10.34105/ j.kmel.2016.08.013.

Margarayn, A., Littlejohn, A., \& Milligan, C. (2011). Collective learning in the workplace: Important knowledge sharing behaviours. International Journal of Advanced Corporate Learning (IJAC), 4(4), 26-31. https://doi.org/10.3991/ijac.v4i4.1801.
Margaryan, A., Littlejohn, A., \& Milligan, C. (2013). Self-regulated learning in the workplace: Strategies and factors in the attainment of learning goals. International Journal of Training and Development, 17(4), 245-259. https://doi.org/10.1111/ijtd.12013.

Mathes, J. (2018). Global quality in online, open, flexible and technology enhanced education: Analysis of strength, weaknesses, opportunities and threats. ICDE. https://static1.squarespace.com/ static/5b99664675f9eea7a3ecee82/t/5dde6fad0c91bc6c3b7be1c8/ 1574858701328/Global+quality+Report+July+2019.pdf.

Ministry of Education and Vocational Training (MoEVT). (2008). Education sector development programme (ESDP) 2008-17: revised edition. United Republic of Tanzania. https://www.ilo. org/dyn/youthpol/en/equest.fileutils.dochandle?p_uploaded_ file_id $=143$.

Ministry of Labor, Employment and Youth Development (2007, December). National youth development policy. Policy. United Republic of Tanzania. https://www.youthpolicy.org/national/ Tanzania_2007_National_Youth_Policy.pdf.

NUFFIC. (2015, January). Education system in Tanzania. https:// www.nuffic.nl/sites/default/files/2020-08/education-systemtanzania.pdf.

Pather, S., \& Slee, R. (2018). Challenging inclusive education policy and practice in Africa. Vol. 40. Boston: BRILL.

Pavlova, M (2014). TVET as an important factor in country's economic development. SpringerPlus, 3, K3. https://doi.org/10. 1186/2193-1801-3-S1-K3.

Silverman, M. (2003). Supporting workplace learning: A background paper for IES research network members. The Institute of Employment Studies. https://www.employment-studies.co.uk/ system/files/resources/files/mp22.pdf.

Slotte, V, \& Tynjälä, P. (2003). Industry-university collaboration for continuing professional development. Journal of Education and Work, 16(4), 445-464. https://doi.org/10.1080/ 136390803200093058.

Tanzania Commission for Universities. (2010). Universities qualifications framework: Final draft. https://www.tcu.go.tz/sites/ default/files/University_Qualifications_Framework.pdf.

Tanzania Commission for Universities. (2010). Summary of the Tanzania national qualification Framework. NQF:Final draft. https://uil.unesco.org/fileadmin/keydocuments/ LifelongLearning/en/Tanzania.pdf.

Tanzania Commission for Universities. (2018). Higher education students admission, Enrollment and graduation statistics. Academic statistics. https://www.tcu.go.tz/sites/default/files/ Admission\%20and\%20Graduation\%20Statistics.pdf.

United Nations (2015). Global sustainable development report, 2015 Edition. UN. https://www.un.org/en/development/desa/ publications/global-sustainable-development-report2015edition.html.

UNESCO (2015). Education for all 2000-2015: Achievements and challenges. https://en.unesco.org/gem-report/report/2015/ education-all-2000-2015-achievements-and-challenges.

United Republic of Tanzania. (2012). Adult and non-formal education development plan (ANFEDP) 2012/13-2016/17. Ministry of Education and Vocational Training (MoEVT). http://www.ilo.org/ dyn/youthpol/en/equest.fileutils.dochandle?p_uploaded_file_ $\mathrm{id}=313$. 
United Republic of Tanzania. (2013). Technical and vocational education and training development program (TVETDP) 2013/ 2014-2017/2018. Ministry of Education and Vocational Training. https://planipolis.iiep.unesco.org/en/2013/technical-andvocational-education-and-training-development-programmetvetdp-20132014-20172018.

United Republic of Tanzania. (2016a). National five year development plan 2016/17-2020/2021. Development plan. Ministry of Finance and Planning. https://mof.go.tz/mofdocs/msemaji/Five \%202016_17_2020_21.pdf.

United Republic of Tanzania. (2016b). Tanzania national information and communications technology policy. Ministry of Works, Transport and Communication. https://www.ictc.go.tz/ index.php/component/phocadownload/category/4-policies? download $=48: 107$.

United Republic of Tanzania. (2017). Education sector development plan (2016/17-2020/21). Ministry of Education, Science and Technology. https://www.globalpartnership.org/sites/default/ files/2019-04-gpe-tanzania-esp.pdf.
United Republic of Tanzania, Tanzania. (2000). The Tanzania development vision 2025. Development plan. Ministry of Finance and Planning. https://mof.go.tz/mofdocs/overarch/vision2025.htm.

Vieira do Nascimento, D. M., \& Valdés-Contera, R. (Eds.) (2018). Promoting lifelong learning for all: The Experiences of Ethiopia, Kenya, Namibia, Rwanda and the unitedmm Republic of Tanzania. Hamburg: UNESCO Institute for Lifelong Learning.

Walters, S., Yang, J., \& Roslander, P. (2012). Key issues and policy considerations in promoting lifelong learning in selected African countries: Ethiopia, Kenya, Namibia, Rwanda and Tanzania. UNESCO Institute for Lifelong Learning. https://unesdoc. unesco.org/ark:/48223/pf0000231157.

Yano, S. (Ed.) (2013). UNESCO Handbook on education policy Analysis and programming (Vol. 1). UNESCO Office Bangkok and Regional Bureau for Education in Asia and the Pacific. https://unesdoc.unesco.org/ark:/48223/pf0000221189.

Zhao, Y., \& Ko, J. (2018). Workplace learning in the professional development of vocational education teachers. Studia Paedagogica, 23(2), 43. https://doi.org/10.5817/SP2018-2-4. 